\title{
Effectiveness of the morphofunctional evaluation method of Campolina and Mangalarga Marchador breeds
}

\section{Jéssyka Emmanuelly Silva dos Santos ${ }^{1}$, Juliano Martins Santiago ${ }^{*}$ (iD), Jorge Eduardo Cavalcante Lucena ${ }^{1}$, Bruna Aparecida dos Santos ${ }^{2}$, Ângela Maria Quintão Lana ${ }^{3}$, Adalgiza Souza Carneiro de Rezende ${ }^{3}$}

\author{
${ }^{1}$ Universidade Federal Rural de Pernambuco, Unidade Acadêmica de Garanhuns, Garanhuns, PE, Brasil. \\ 2 Universidade Federal Rural de Pernambuco, Unidade Acadêmica de Serra Talhada, Serra Talhada, PE, Brasil. \\ ${ }^{3}$ Universidade Federal de Minas Gerais, Escola de Veterinária, Departamento de Zootecnia, Belo Horizonte, MG, Brasil.
}

\begin{abstract}
This study aimed to verify whether the criterion of exhibition contests adopted for Campolina and Mangalarga Marchador breeds has been successful in recent years, i.e., if the subsequent generations have the morphology recommended by the standard of the breed allied with high-quality marcha, a four-beat ambling gait. The classifications achieved by each horse during national horse shows in morphology and gait contests underwent Spearman's correlation to verify the number of contests with a correlation between the classifications in the two judgments and those with no correlation. Next, the number of contests with or without such correlation underwent a frequency distribution test considering the variables breed, year, age, marcha category, and sex. Spearman's correlation coefficient (r) of contests with a correlation was also used as a parameter. A difference was observed among years of evaluation only for Mangalarga Marchador horses, with a greater number of contests with correlations between morphological and ambling gait performances between 1998 and 2004. On both breeds, the correlation was found in more contests among foals than adult horses. When Spearman's correlation coefficients were compared, Campolina contests exhibited a higher $r$ than Mangalarga Marchador, 68.14 and 63.68\%, respectively. Only Mangalarga Marchador males had higher $\mathrm{r}$ value than females, 67.27 and $59.73 \%$, respectively. The contest criterion adopted by Campolina and Mangalarga Marchador associations to select superior individuals does not correlate, in subsequent generations, with the morphology recommended by the standard of the breeds with high-quality marcha progress in the same individuals.
\end{abstract}

Key Words: equine, horse, morphometry

\section{Introduction}

Equine locomotion involves movements of the whole body in automated rhythm and patterns that define different gaits (Barrey, 2001). In Brazil, the vast territory and poor roadways have led to marching horses being valued and sought after. According to Beck (1992), the country holds the largest number of horse breeds with a four-beat ambling gait, known as marcha, which is one of the genetic treasures of Brazilian animal performance culture.

The Mangalarga Marchador breed makes up the largest herd of marching horses in Brazil. Those animals have a naturally marching gait, which, allied with docility and rusticity, favor their use in the typical activities of this

Received: October 18, 2017

Accepted: March 13, 2018

*Corresponding author: jmartinssantiago@yahoo.com.br

Copyright (C) 2018 Sociedade Brasileira de Zootecnia. This is an Open Access article distributed under the terms of the Creative Commons Attribution License (http://creativecommons.org/licenses/by/4.0/), which permits unrestricted use, distribution, and reproduction in any medium, provided the original work is properly cited. breed (Fonseca et al., 2017). Another Brazilian breed of marching horses, which constitutes a significant portion of the national herd, is Campolina. It was created in 1870 by Cassiano Campolina, a breeder who sought large, robust, sturdy horses with a comfortable gait to be used in rural work, sport, and leisure (Lucena et al., 2016).

In the first contests held by the Associação Brasileira de Criadores do Cavalo Mangalarga Marchador (ABCCMM) and the Associação Brasileira de Criadores do Cavalo Campolina (ABCCC), only animal morphology was evaluated, and the champion was the horse that best fit the standards of the breeds. Marcha was not scored, although it was an eliminatory criterion. However, concerned about matching animal morphology with their quality marcha gait, the associations resolved that, during contests, horses must undergo both a morphology and a gait trial, each with weight of $50 \%$. Therefore, the final score obtained by each animal results from the sum of its results in the two criteria, and the title of champion will be awarded to the horse with the best overall score. 
Besides the economic importance of nationwide horse shows, such events, by gathering the best specimens of the breed, lay bases for breeders, technicians, and judges to select among stud farms the most adequate breeders to produce the next generations (Costa et al., 2006). In this context, this study aimed to verify whether the judgment criterion adopted by the $\mathrm{ABCCMM}$ and $\mathrm{ABCCC}$ has been successful in recent years, i.e., whether the following generations indeed featured the morphology recommended by the standards of the breeds associated with quality marcha gait.

\section{Material and Methods}

The study was carried out using information from the ABCCMM and ABCCC databases. The contest results of national horse shows between 1998 and 2016 were obtained from the ABCCMM database, for a total of 643 contests involving 8,051 animals judged. The ABCCC database, with results of contest in national horse shows between 2013 and 2016, yielded a total of 134 contests involving 1,089 animals judged.

Contest results were separated by breed (Campolina and Mangalarga Marchador), year (1998 to 2016), age (young animals presented led by the halter for gait evaluation and adult animals ridden during the gait contest), gait category (marcha batida and marcha picada), and sex (males and females) using the software Microsoft Excel (version 2013). Next, the classifications achieved by each horse in the morphology and marcha contests underwent Spearman's correlation to reveal the number of contests with a correlation $(\mathrm{P}<0.05)$ between morphology and marcha contest classifications or with no such correlation ( $\mathrm{P}>0.05)$ using the statistical software Graphpad Instat (version 3.3).

The number of contests with the correlation of interest $(\mathrm{P}<0.05)$ was used as a parameter to compare the variables breed, year, age, gait category, and sex and underwent a frequency distribution (chi-squared) test using the software Sisvar (version 5.6).

Moreover, Spearman's correlation coefficients $(r)$ of the contests with a correlation $(\mathrm{P}<0.05)$ between morphology and marcha judgments were used as parameter. Thus, to compare the variables breed, age, gait category, and sex, the correlation coefficients underwent Mann-Whitney nonparametric test, whereas, to compare the evaluation years (1998 to 2016), the correlation coefficients underwent Kruskal-Wallis non-parametric test using the statistical software Graphpad Instat (version 3.3).

\section{Results}

No difference $(\mathrm{P}=0.0822)$ was found between the Campolina and Mangalarga Marchador breeds regarding the number of contests with a correlation between morphology and marcha classifications (Table 1). For Campolina, $88 \%$ of the contests assessed had no such correlation. A similar result was found in Mangalarga Marchador contests, of which $81 \%$ had no correlation between the two classifications.

A difference $(\mathrm{P}=0.0323)$ was found among the years investigated only for Mangalarga Marchador, with the highest percentage (30\%) of contests between 1998 and 2004 showing correlations $(\mathrm{P}<0.05)$ between the classifications in the morphology and marcha trials. In

Table 1 - Results of the $\chi^{2}$ and P-values for the five variables, considering the number of contests with a correlation or with no correlation between the classifications in morphology and gait judgments of the two breeds, expressed as the number of contests $(\mathrm{N})$ and percentage $(\%)$

\begin{tabular}{|c|c|c|c|c|c|c|}
\hline \multirow{2}{*}{ Variable } & \multicolumn{2}{|c|}{ Correlation } & \multicolumn{2}{|c|}{ No correlation } & \multirow{2}{*}{$\chi^{2}$} & \multirow{2}{*}{ P-value } \\
\hline & $\mathrm{N}$ & $\%$ & $\mathrm{~N}$ & $\%$ & & \\
\hline Mangalarga Marchador & 120 & 19 & 523 & 81 & \multirow{2}{*}{3.02} & \multirow{2}{*}{0.0822} \\
\hline \multirow[t]{2}{*}{ Campolina } & 16 & 12 & 118 & 88 & & \\
\hline & \multicolumn{4}{|c|}{ Mangalarga Marchador } & & \\
\hline \multicolumn{7}{|l|}{ Time } \\
\hline 1998-2004 & 19 & 30 & 44 & 70 & \multirow{5}{*}{10.53} & \multirow{5}{*}{0.0323} \\
\hline $2005-2007$ & 10 & 19 & 42 & 81 & & \\
\hline $2008-2010$ & 32 & 20 & 128 & 80 & & \\
\hline 2011-2013 & 36 & 20 & 147 & 80 & & \\
\hline 2014-2016 & 23 & 12 & 162 & 88 & & \\
\hline \multicolumn{7}{|l|}{ Age group } \\
\hline Foals & 75 & 35 & 141 & 65 & \multirow[t]{2}{*}{53.68} & \multirow[t]{2}{*}{0.0001} \\
\hline Adults & 45 & 11 & 382 & 89 & & \\
\hline \multicolumn{7}{|l|}{ Marcha } \\
\hline Batida & 33 & 11 & 256 & 89 & \multirow[t]{2}{*}{0.47} & \multirow[t]{2}{*}{0.4911} \\
\hline Picada & 12 & 09 & 126 & 91 & & \\
\hline \multicolumn{7}{|l|}{ Sex } \\
\hline Females & 60 & 19 & 264 & 81 & \multirow[t]{2}{*}{0.00} & \multirow[t]{2}{*}{0.9946} \\
\hline \multirow[t]{2}{*}{ Males } & 60 & 19 & 259 & 81 & & \\
\hline & \multicolumn{4}{|c|}{ Campolina } & & \\
\hline \multicolumn{7}{|l|}{ Time } \\
\hline 2013 & 04 & 11 & 31 & 89 & \multirow{4}{*}{2.23} & \multirow{4}{*}{0.5269} \\
\hline 2014 & 02 & 06 & 32 & 94 & & \\
\hline 2015 & 05 & 14 & 31 & 86 & & \\
\hline 2016 & 05 & 17 & 24 & 83 & & \\
\hline \multicolumn{7}{|l|}{ Age group } \\
\hline Led & 11 & 24 & 35 & 76 & \multirow[t]{2}{*}{7.89} & 0.0049 \\
\hline Ridden & 05 & 06 & 83 & 94 & & \\
\hline Marcha & & & & & & \\
\hline Batida & 03 & 05 & 56 & 95 & 0.02 & 0.8849 \\
\hline Picada & 02 & 07 & 27 & 93 & & \\
\hline Sex & & & & & & \\
\hline Females & 09 & 12 & 69 & 88 & 0.01 & 0.9197 \\
\hline Males & 07 & 13 & 49 & 88 & & \\
\hline
\end{tabular}


the other years, a progressive reduction in the number of contests with correlations $(\mathrm{P}<0.05)$ between the two classifications was observed $\left(\mathrm{R}^{2}=80.38\right)$ (Figure 1$)$.

In both breeds, foals ( $<36$ months), judged while led by the halter, had more contests with a correlation between morphology and gait judgments than adult horses (>36 months), evaluated while being ridden. For Mangalarga Marchador horses, $35 \%$ of the foal contests had a correlation between morphology and marcha, whereas only $11 \%$ of adult horse contests had such association. For Campolina, the correlation was found in $24 \%$ of foal and $6 \%$ of adult contests.

The type of gait - marcha batida and marcha picada - did not impact the number of contests with a correlation between morphology and gait scores for both Mangalarga Marchador ( $\mathrm{P}=0.4911)$ and Campolina $(\mathrm{P}=0.8849)$. In marcha batida evaluations of Mangalarga Marchador and Campolina horses, 11 and $5 \%$ of the contests, respectively, had a correlation between morphology and gait results, whereas 9 and 7\%, respectively, of the marcha picada contests had such correlation.

No difference was found in the number of contests with a correlation between the morphology and gait rankings between male and female Mangalarga Marchador $(\mathrm{P}=0.9946)$ or Campolina $(\mathrm{P}=0.9197)$ horses. Mangalarga Marchador animals of either sex had a similar proportion of contests with an association between morphology and marcha $(19 \%)$, whereas this proportion was very close among Campolina horses, of 13 and $12 \%$, respectively.

When Spearman's correlation coefficients (r) of the contests with the correlation $(\mathrm{P}<0.05)$ of interest were compared, a difference $(\mathrm{P}=0.0156)$ was found between the $\mathrm{r}$ values of the Mangalarga Marchador and Campolina breeds, of 63.68 (-61.82-91.67) and 68.14\% (55.25-90.00), respectively (Table 2$)$.

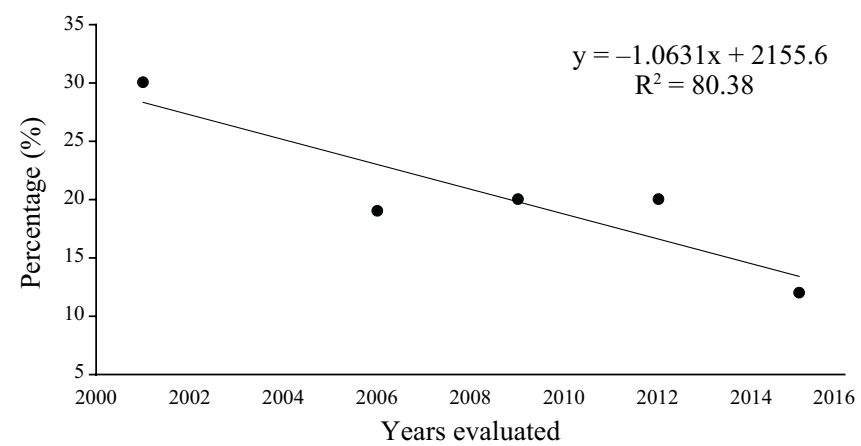

Figure 1 - Percentage of contests with a correlation $(\mathrm{P}<0.05)$ between classifications in morphology and gait judgments in the national horse shows of the Mangalarga Marchador breed between 1998 and 2016.
For both breeds, no difference was found in $\mathrm{r}$ values when comparing the variables time, age group, and gait type. Male Mangalarga Marchador horses had a higher $\mathrm{r}$ value than females, at $67.27 \%(-61.82-86.26)$ and $59.73 \%$ (-60.14-91.67), respectively, which was not observed for Campolina animals.

\section{Discussion}

The low percentage of contests with a correlation between the classifications in morphology and marcha rankings for Mangalarga Marchador (19\%) and Campolina $(12 \%)$ horses may be related to the criteria adopted in the morphology judgment of those animals.

The methodology employed by judges when evaluating horses of either breed externally is guided by the same scoring charts used by technicians when evaluating a horse to provide the definitive genealogic registration. Those tables attribute a score to each region of the animal body.

Table 2 - Medians and lower and upper thresholds $\left(\mathrm{T}_{1}-\mathrm{T}_{\mathrm{u}}\right)$ of Spearman's correlation coefficients of the contests with a correlation between the classifications of morphology and gait judgments of the two breeds for the five variables of the significant correlations

\begin{tabular}{|c|c|c|c|}
\hline Variable & Median & $\mathrm{T}_{1}-\mathrm{T}_{\mathrm{u}}$ & P-value \\
\hline Campolina $(\mathrm{n}=16)$ & $68.14 \mathrm{a}$ & $55.25-90.00$ & \multirow{2}{*}{0.0156} \\
\hline \multirow[t]{2}{*}{ Mangalarga Marchador $(\mathrm{n}=120)$} & $63.68 \mathrm{~b}$ & $-61.82-91.67$ & \\
\hline & \multicolumn{2}{|c|}{ Mangalarga Marchador } & \\
\hline \multicolumn{4}{|l|}{ Time } \\
\hline $1998-2004(n=19)$ & 60.05 & $-54.29-78.12$ & \multirow{5}{*}{0.8726} \\
\hline $2005-2007(\mathrm{n}=10)$ & 62.48 & $54.64-70.99$ & \\
\hline $2008-2010(\mathrm{n}=32)$ & 64.16 & $48.40-91.67$ & \\
\hline $2011-2013(n=36)$ & 63.21 & $-61.82-83.03$ & \\
\hline $2014-2016(n=23)$ & 66.43 & $-60.14-75.52$ & \\
\hline \multicolumn{4}{|l|}{ Age group } \\
\hline Foals $(\mathrm{n}=75)$ & 64.84 & $46.81-86.26$ & \multirow[t]{2}{*}{0.3082} \\
\hline Adults $(\mathrm{n}=45)$ & 61.76 & $-61.82-91.67$ & \\
\hline \multicolumn{4}{|l|}{ Marcha } \\
\hline Batida $(\mathrm{n}=33)$ & 60.88 & $-55.39-80.00$ & \multirow[t]{2}{*}{0.1401} \\
\hline Picada $(\mathrm{n}=12)$ & 68.24 & $-61.82-91.67$ & \\
\hline \multicolumn{4}{|l|}{ Sex } \\
\hline Females $(\mathrm{n}=60)$ & $59.73 b$ & $-60.14-91.67$ & \multirow[t]{2}{*}{0.0003} \\
\hline \multirow[t]{2}{*}{ Males $(n=60)$} & $67.27 \mathrm{a}$ & $-61.82-86.26$ & \\
\hline & \multicolumn{2}{|c|}{ Campolina } & \\
\hline \multicolumn{4}{|l|}{ Time } \\
\hline $2013(n=04)$ & 62.77 & $57.31-84.74$ & \multirow{4}{*}{0.1260} \\
\hline $2014(\mathrm{n}=02)$ & 58.61 & $55.25-61.96$ & \\
\hline $2015(n=05)$ & 80.00 & $59.23-83.33$ & \\
\hline $2016(\mathrm{n}=05)$ & 83.33 & $64.29-90.00$ & \\
\hline \multicolumn{4}{|l|}{ Age group } \\
\hline Foals $(\mathrm{n}=11)$ & 64.25 & $55.25-88.33$ & \multirow[t]{2}{*}{0.1567} \\
\hline Adults $(\mathrm{n}=05)$ & 82.86 & $64.29-90.00$ & \\
\hline \multicolumn{4}{|l|}{ Sex } \\
\hline Females $(\mathrm{n}=09)$ & 64.85 & $57.31-88.33$ & \multirow[t]{2}{*}{0.8738} \\
\hline Males $(\mathrm{n}=07)$ & 82.86 & $55.25-90.00$ & \\
\hline
\end{tabular}

Different letters in the columns differ according to Mann-Whitney test $(\mathrm{P}<0.05)$. 
However, a considerable part of the animal performance regions scored are related more to the characterization of the breed than to its marching gait. In Campolina animals, for example, over $40 \%$ of the score is attributed to regions of the body and morphological characteristics that would hardly impact marcha, such as coat, head shape and profile, ears, forehead, jaw, eyes, supraorbital fossae, and mouth (SRGCC, 2017). Therefore, even if associations, breeders, technicians, and judges aim to associate horse morphology with quality gait, the practice of scoring regions of the body unrelated to marcha in morphology judgments likely hampers achieving such goal.

According to Deerinck (2012), there are still only hypotheses on the origin and genetic factor of marcha. Some believe marcha results from a specific recessive gene, while others assume it was an adaptation of the horse to the environment, and many consider that the origin of gait comes from a confluence of these two factors: environment and genetics. The theory by Dr. Ann Staiger, who studies marcha genetics at Cornell University, seems more likely and is based on the hypothesis that the marcha is influenced by several genes. Supporting this hypothesis, Andersson et al. (2012) attributed to a mutation in gene DMRT3 the ability of horses to dissociate pelvic and thoracic limbs during marcha and, more recently, Patterson et al. (2015), besides identifying the mutant allele DMRT3 in Mangalarga Marchador horses, found a variation in the frequency of this gene according to the type of marcha, batida and picada.

Thus, although morphology contributes to the quality of movement in horses, genetic factors will effectively determine the marching gait in these animals. Associated with this hypothesis, two other factors must be considered in face of the results of the present study: the marcha diagram and physical compensations.

When evaluating horse morphofunction, judges value the movement capacity of animals, whether they have adequate physical proportions required for good balance, angulations to perform broader movements, and well-developed musculature that provides power to the movement. However, the marcha diagram, one of the main items assessed in the gait judgment of marching horses, does not depend on those characteristics. That justifies the existence of well-conformed horses with proper proportions, angulations, and muscle development for marcha whose diagrams, nonetheless, have little dissociation, being more diagonalized or lateralized.

In animal sciences, "physical compensations" are qualities in regions close to the technical defect that compensate or minimize the effects of such defects on animal function (McManus et al., 2005; Santiago et al., 2016). Thus, horses with flaws in some regions of the body may be penalized in the morphological judgment and, due to physical compensations that neutralize these defects, perform well in marcha judgments, which hampers correlating the results of the two judgments.

The condition in which the animal is presented may also have contributed to the low percentage of contests with an association between morphology and marcha. Horses with better visual aspect, greater muscle development, and smooth, shiny coats call more attention of judges during morphological contests and, consequently, tend to rank at the top in competitions. However, such characteristics do not necessarily impact the quality of movement of marching horses. Therefore, animals with lower body score and/or with poorer visuals may be penalized in the morphology judgment while achieving excellent performance in the marcha trial.

It is important to point out that, in the present study, only the judgment results of national horse shows of either breed were analyzed, i.e., results of regional shows, occurring all over the country every year, were not taken into account. Restricting the analysis to only data of nationwide shows is justified by the fact that a national horse show is the main event for both breeds, since, besides closing the equestrian year, they feature horses qualified in the regional shows. It is possible that the animals with important morphological regions for marcha quality have been previously selected in regional shows, thus standardizing the animals that attend the national shows for those aspects. That may have contributed to the low percentage of contests with a correlation between morphology and marcha judgments in national horse shows of Campolina and Mangalarga Marchador breeds.

Between 1998 and 2016, the progressive reduction in the number of contests with a correlation between the classifications of those two trials for Mangalarga Marchador horses may be related to greater herd standardization during that period. According to Procópio (2012), champion male and female horses of this breed produce more offspring compared with non-champion ones, since they have better morphological and functional qualities. This genetic improvement process seeks to increasingly approximate Mangalarga Marchador horses to the standard of the breed, which leads to a more homogeneous herd.

In this sense, the physically and functionally closer the horses are in a contest, the harder is to define the best ones. In face of such difficulty, judges often use morphological characteristics little related to quality of movement as 
criteria to differentiate animals, as well as scoring items in the marcha evaluation unrelated to the functional quality of animals, such as rideability and fitness. Therefore, the homogenization of the Mangalarga Marchador herd and the consequent difficulty in defining the best specimens may justify the progressive decrease of contests with an association between marcha and morphology.

For the Campolina breed, the method that attributes equal weight to either judgment was adopted only in 2013. For this reason, the present study compared only the results of national horse shows between 2013 and 2016. This way, the similarity in the number of contests with a correlation between the classifications of both aspects may be related to the short timeframe considered, of four years, unlike the 19 years of results for the Mangalarga Marchador breed.

In both breeds, the fact that foals had a greater number of contests with a correlation between the two classifications compared with adult horses may be related to the way young animals are presented. In the marcha trial, foals $(<36$ months) are presented being led by the halter, whereas adults ( $>36$ months) are ridden. Although, in theory, the marcha trials of both young and adult horses are based on the same parameters, it is possible that the ability of the presenters of the former has a greater impact on the final result than the influence of presenters when riding the animals.

In addition, among the items considered in a marcha trial, the second most relevant aspect is gait comfort. However, this characteristic can only be effectively assessed by judges when they ride the animal. When evaluating the gait comfort of foals, judges are only able to analyze trunk stability by observing the vertical movement of the thorax upper line. Thus, the ability of presenters to lead the foals may, again, cause horses to adopt an artificial marcha gait. Other characteristics the judges are not able to accurately evaluate in animals led by the halter is their rideability and capacity of maintaining the marcha diagram and gait elasticity at collected marcha, marcha, and extended marcha.

The rulebooks of national horse shows of either breed state that the presenter must hold the lead line instead of the halter when leading the foal in marcha trials, which prevents the animal from being led with an unnatural posture of the head, neck, and body. However, few presenters comply with this requirement since there is no severe penalty for not doing so. In practice, most presenters hold the foals by the halter, which greatly changes their center of gravity and, consequently, makes their naturally marching gait artificial. That once again supports the hypothesis that the ability of the presenter may strongly impact the final classification of contests when the horses compete being led.

Although the linear measurements and angles may determine the type of movement horses are able to perform (Harris, 1993), marchas batida and picada are related to the movement that differentiates the gait of animals in each category (Santiago et al., 2014). For that reason, the number of contests with a correlation between morphology and gait was expected to be similar for both types of marcha since the evaluation methodology applied was the same.

Although at the national horse shows of either breed, males and females compete in different categories, in many equestrian sports, both sexes compete together so that sexual dimorphism does not prevent the animal from expressing its maximum potential (Cywinska et al., 2011). Thus, the similarity between males and females regarding the number of contests with a correlation between morphology and marcha was also expected.

The highest Spearman's correlation (r) value recorded in Campolina contests (68.14\%) compared with the $r$ value in Mangalarga Marchador contests $(63.68 \%)$ is likely related to the short period of Campolina breed evaluations, from 2013 to 2016 . The results of only four years of national horse shows yielded only 16 contests with a correlation between morphology and marcha to be analyzed, which resulted in a small range of variation: lower threshold of $55.25 \%$ and upper threshold of $90 \%$. In contrast, the 19 years of national shows of the Mangalarga Marchador breed resulted in 120 contests with an association between the two aspects, which, in turn, yielded a greater range of variation: lower threshold of $-61.82 \%$ and upper threshold of $91.67 \%$.

Although the Campolina breed had a higher $r$ value, both breeds had Spearman's correlation coefficient medians between 30 and $70 \%$, which means the associations between morphology and function of the Campolina and Mangalarga Marchador breeds are moderate correlations.

When technicians of either breed evaluate horses applying for the definitive genealogic registration, they use the same scoring chart for both males and females. However, the rules for awarding the genealogic registration require that, after the scores pertaining to each of the technical regions in the scoring chart are added up, the males must reach at least 140 points. For females of this breed, the minimum is 120 points (SRGCMM, 2016). The stricter evaluation of males is important, since, over their reproductive lives, studs produce more offspring than females, which contributes more to the genetic improvement of the breed (Pereira, 2012). Hence, the difference between 
males and females in the minimum score required for the genealogic registration may have contributed to the higher $\mathrm{r}$ value found among Mangalarga Marchador males $(67.27 \%)$ compared with females (59.73\%).

\section{Conclusions}

The judgment methodology adopted by the associations to select the Campolina and Mangalarga Marchador breeds does not correlate, in the following generations, with the morphology recommended by the standard of the breeds and quality gait in the same animals.

\section{References}

Andersson, L. S.; Larhammar, M.; Memic, F.; Wootz, H.; Schwochow, D.; Rubin, C. J.; Patra, K.; Arnason, T.; Wellbring, L.; Hjälm, G.; Imsland, F.; Petersen, J. L.; McCue, M. E.; Mickelson, J. R.; Cothran, G.; Ahituv, N.; Roepstorff, L.; Mikko, S.; Vallstedt, A.; Lindgren, G.; Andersson, L. and Kullander, K. 2012. Mutations in DMRT3 affect locomotion in horses and spinal circuit function in mice. Nature 488:642-646. https://doi.org/10.1038/nature11399

Barrey, E. 2001. Inter-limb coordination. p.77-94. In: Equine locomotion. Back, W. and Clayton, H., eds. Saunders, London.

Beck, S. L. 1992. Mangalarga Marchador, caracterização, história, seleção. Edição dos Autores, Brasília, DF.

Costa, H. G.; Costa, J. A. B. and Caiado, J. R. C. 2006. Evaluation of equine "Mangalarga Marchador": a multicriteria analysis by ELECTRE II method. Revista Pesquisa e Desenvolvimento Engenharia de Produção (5):1-17.

Cywinska, A.; Szarska, E.; Kowalska, A.; Ostaszewskic, P. and Schollenberger, A. 2011. Gender differences in exercise - induced intravascular haemolysis during race training in thoroughbred horses. Research in Veterinary Science 90:133-137.

Deerinck, A. 2012. Um cavalo que faz sonhar. Revista Mangalarga Marchador 23:42-45.

Fonseca, M. G.; Ferraz, G. C.; Lage, J.; Pereira, G. L. and Curi, R. A. 2017. A genome-wide association study reveals differences in the genetic mechanism of control of the two gait patterns of the Brazilian
Mangalarga Marchador breed. Journal of Equine Veterinary Science 53:64-67. https://doi.org/10.1016/j.jevs.2016.01.015

Harris, S. E. 1993. The gaits and transitions. p.32-63. In: Horse gaits, balance and movement. Harris, S. E., Howell Book House, New York.

Lucena, J. E. C.; Vianna, S. A. B.; Berbari Neto, F.; Sales Filho, R. L. M. and Diniz, W. J. S. 2016. Caracterização morfométrica de fêmeas, garanhões e castrados da raça Campolina baseada em índices. Arquivo Brasileiro de Medicina Veterinária e Zootecnia 68:431-438. https://doi.org/10.1590/1678-4162-8016

McManus, C.; Falcão, R. A.; Spritze, A.; Costa, D.; Louvandini, H.; Dias, L. T.; Teixeira, R. A.; Rezende, M. J. M. and Garcia, J. A. S. 2005. Caracterização morfológica de eqüinos da raça Campeiro. Revista Brasileira de Zootecnia 34:1553-1562. https://doi.org/10.1590/S1516-35982005000500015

Patterson, L.; Staiger, E. A. and Brooks, S. A. 2015. DMRT3 is associated with gait type in Mangalarga Marchador horses, but does not control gait ability. Animal Genetics 46:213-215. https://doi.org/10.1111/age.12273

Pereira, J. C. C. 2012. Melhoramento genético aplicado à produção animal. FEPMVZ, Belo Horizonte.

Procópio, A. M. 2012. Melhoramento genético aplicado aos equinos. p.428-442. In: Melhoramento genético aplicado à produção animal. Pereira, J. C. C. FEPMVZ, Belo Horizonte.

Santiago, J. M.; Rezende, A. S. C.; Lana, A. M. Q.; Fonseca, M. G and Lage, J. 2014. Comparação entre as medidas morfométricas de equinos Mangalarga Marchador de marcha picada e marcha batida. Arquivo Brasileiro de Medicina Veterinária e Zootecnia 66:635-639. https://doi.org/10.1590/1678-41626870

Santiago, J. M.; Rezende, A. S. C.; Lana, A. M. Q.; Fonseca, M. G. and Lage, J. 2016. Evolution of morphometric measures in the Mangalarga Marchador breed. Revista Caatinga 29:191-199. https://doi.org/10.1590/1983-21252016v29n122rc

SRGCC - Serviço do Registro Genealógico do Cavalo Campolina. 2017. Regulamento do serviço do registro genealógico do cavalo Campolina. Available at: <http://www.campolina.org.br/portal/ download/regulamentos/REGULAMENTO\%20MAPA \%20-\%20 20.07.2017.pdf $>$. Accessed on: Sept. 19, 2017.

SRGCMM - Serviço do Registro Genealógico do Cavalo Mangalarga Marchador. 2016. Regulamento do serviço do registro genealógico do cavalo Mangalarga Marchador. Available at: <http://leia. abccmm.org.br/portal/regulamentos/regulamentosrg/>. Accessed on: Sept. 19, 2017. 